\title{
Comparative study of nifepidine and isoxsuprine in suppression of preterm labour
}

\author{
Prerna Jain $^{1}$, Supriya Suman ${ }^{1}$, Manju Gita Mishra ${ }^{2}$ \\ ${ }^{1}$ Department of Obstetrics and Gynecology, F.H. Medical College and Hospital, Tundla Firozabad, Uttar Pradesh, \\ India \\ ${ }^{2}$ Department of Obstetrics and Gynecology, M.G.M. Hospital and Research Center, Patna, Bihar, India
}

Received: 07 October 2016

Revised: 12 October 2016

Accepted: 15 October 2016

\author{
*Correspondence: \\ Dr. Prerna Jain, \\ E-mail: drpjaiims@gmail.com
}

Copyright: ( $\odot$ the author(s), publisher and licensee Medip Academy. This is an open-access article distributed under the terms of the Creative Commons Attribution Non-Commercial License, which permits unrestricted non-commercial use, distribution, and reproduction in any medium, provided the original work is properly cited.

\begin{abstract}
Background: A prospective study was conducted to compare the efficacy of nifedipine against isoxsuprine in preventing preterm labour and also to evaluate maternal side effects and neonatal outcome.

Methods: This was a randomized prospective comparative study done at MGM hospital and research center, Patna, Bihar between 15/03/2014 to 15/02/2016. 75 antenatal women with gestational age between 28 to 36 weeks were selected who fulfilled the inclusion criteria for the study, were given nifedipine and were monitored throughout the course of treatment.

Results: Groups were compared with mean prolongation of delivery, side effects, neonatal outcome, parity, cervical effacements. Nifedipine was twice more effective than isoxsuprine hydrochloride as a uterine tocolytic agent while side effects were comparable with fewer side effects in nifedipine group. Neonatal outcome was better with nifedipine in comparison to isoxsuprine.

Conclusions: There is a high incidence of preterm labour in India. The present study found that nifedipine has better tocolytic efficacy, less side effects and better tolerability as compared to isoxsuprine.
\end{abstract}

Keywords: Preterm labor, Tocolytics, Nifedipine, Isoxsuprine hydrochloride, Ritodrine

\section{INTRODUCTION}

Preterm labor remains one of the unconquered frontiers in the present era of obstetrics. Its incidence is about 7-9\% of pregnancies accounting for three quarters of the mortality and morbidity among newborns without congenital anomalies. ${ }^{1}$ Preterm delivery affects $11 \%$ in United States or even greater in developing countries (23.3\% in India) and it accounts for $40-75 \%$ of neonatal deaths. $^{2,3}$

Throughout the years a variety of drugs with different pharmacologic principles are used to suppress preterm labour. The choice is limited by their efficacy, safety and side effects. Ritodrine, beta sympathomimetic is one such agent which is commonly used tocolytic. It has serious maternal and fetal side effects limiting its use. ${ }^{4}$ Beta adrenergic receptor blocking agent isoxsuprine and nifedipine, a calcium channel blocking agent is the most widely used tocolytic agent in India. ${ }^{5}$ Several nonrandomized and randomized trials suggest that nifedipine is effective in suppressing preterm labor with minimal side effects on the mother and fetus. ${ }^{1,6-8}$ nifedipine is an effective smooth muscle relaxant with low toxicity and low teratogenicity. ${ }^{9}$ There is a growing body of nifedepine, that it is an effective, potentially safer and better tolerated tocolytic agent with no known fetal side effects. This study compares in a prospective design, the efficacy and safety results of nifedipine with that of isoxsuprine in the expression of preterm labour and also 
to compare maternal and perinatal outcome in these patients.

\section{METHODS}

This was a prospective study of 75 antenatal women conducted at MGM hospital and research center Patna, Bihar in the department of obstetrics and Gynecology. Written informed consent was taken from the subjects recruited in the study from 15/03/2014 to $15 / 02 / 2016$. Patient included in the study were between 28-36 weeks of gestational age and four uterine contractions in $20 \mathrm{~min}$ with or without cervical dilatation more than $1 \mathrm{~cm}$ or effacement $80 \%$ or greater were recruited in the study as per the ACOG criteria.

Female patients with more than 36 completed weeks, those in active labour $(>4 \mathrm{~cm}$ dilatation), those with severe pregnancy induced hypertension, eclampsia, gestational Diabetes mellitus, cardiac disease, Abruptio placenta, chorio-amnionitis, fetal distress, fetal anomaly, hyperthyroidism were excluded from the study. For group 1 , who received nifedipine were given $20 \mathrm{mg}$ oral nifedipine initially followed by $10 \mathrm{mg}$ at four hour interval for 48 hour. If contractions persisted at $90 \mathrm{~min}$, the first $10 \mathrm{mg}$ dose was started at the same time. For group 2, patient were started on infusion of injection isoxsuprine $40 \mathrm{mg}$ in $500 \mathrm{ml}$ ringer lactate at $0.08 \mathrm{mg} / \mathrm{min}$, increasing the infusion rate up to $0.24 \mathrm{mg} / \mathrm{min}$ depending on the status of uterine contractions and occurrence of side effects. After discontinuation of intravenous infusion, patient's were maintained on oral isoxsuprine $10 \mathrm{mg}$ eight hourly for upto 7 days. Either of the treatment was discontinued if no uterine contraction occurred within 48 hours.

Vital signs, uterine contractions and fetal heart sound were monitored half hourly and side effects were noted until the patient was discharged from labour ward and started on maintenance doses. All patients received injection Betamethasone 12mg intramuscularly for two doses 24hours apart, to enhance fetal lung maturation. All the patients were followed up weekly for cervical dilatation. Goal of tocolysis was to delay delivery for 24hours, in patient with ruptured membranes and through 36 completed weeks of gestation in patients with intact membranes. Tocolysis was considered failed if uterine quiescence was not achieved despite maximum dose and delivery occurred within 48hours. Data regarding mean prolongation of pregnancy (at 48hour, 1 week, 37 weeks), side effects, failure of treatment, gestational age at delivery and neonatal death were recorded. In this hospital, incidence was $24 \%$ during the study period.

\section{RESULTS}

During the prospective study of 75 women who received oral nifedepine following results were found.
Table 1: Mean prolongation of delivery.

\begin{tabular}{|lll|}
\hline Age (years) & Nifedipine & Isoxsuprine \\
\hline $\begin{array}{l}\text { Parity } \\
\text { Primgravida }\end{array}$ & $22.2 \pm 5.5$ & $23.4 \pm 4.6$ \\
\hline $\begin{array}{l}\text { Multigravida } \\
\begin{array}{l}\text { Gestation at treatment (in } \\
\text { Weeks) }\end{array}\end{array}$ & $67(10 \%)$ & $60(80 \%)$ \\
\hline $\begin{array}{l}\text { Mean prolongation of } \\
\text { delivery (in days) }\end{array}$ & $22.4 \pm 15(20 \%)$ \\
\hline
\end{tabular}

In group I, $90 \%$ of patient was primigravida with mean age of 22.2 $\pm 5.5 \mathrm{Yrs}$ and with mean gestation at treatment was $30.5 \pm 3.5$ Weeks and mean prolongation of delivery was $22.4 \pm 15.6$ days where as with the isoxsuprine in group II patient mean prolongation of delivery was $16.5 \pm 14.5$ days.

Table 2: Pregnancy outcome.

\begin{tabular}{|lll|}
\hline Success & $\begin{array}{l}\text { Nifedipine } \\
\text { n(\%) }\end{array}$ & $\begin{array}{l}\text { Isoxsuprine } \\
\text { n }(\%)\end{array}$ \\
\hline Failure & $67(90 \%)$ & $57(76 \%)$ \\
\hline Total & $8(10 \%)$ & $18(24 \%)$ \\
\hline
\end{tabular}

$\mathrm{n}=$ no. of patient

From Table 2, we conclude that $90 \%$ success rate was seen in group I while the success rate in group II was only $76 \%$.

Table 3: Side effects.

\begin{tabular}{|lll|}
\hline & $\begin{array}{l}\text { Nifedipine } \\
\text { n (\%) }\end{array}$ & $\begin{array}{l}\text { Isoxsuprine } \\
\text { n (\%) }\end{array}$ \\
\hline Tachycardia & $35(76 \%)$ & $42(50 \%)$ \\
\hline Hypotension & $15(20 \%)$ & $27(36 \%)$ \\
\hline Nausea/Vomiting & $7(10 \%)$ & $25(34 \%)$ \\
\hline Chest pain & $3(4 \%)$ & $7(10 \%)$ \\
\hline Pulmonary edema & 0 & $7(2 \%)$ \\
\hline Hot flushes (transient) & $30(40 \%)$ & $26(39 \%)$ \\
\hline Headache & $27(30 \%)$ & $9(12 \%)$ \\
\hline
\end{tabular}

Nausea, vomiting, headache and palpitation were main side effects in both the group. More Incidences of $40 \%$ transient hot flushes was seen in group A than in group B. Pulmonary edema was reported in 1 case with isoxsuprine, following which therapy was discontinued. Hypotension and tachycardia were commonest maternal side effects (Table 3).

\section{DISCUSSION}

Incidence of preterm labor is quite high in our country compared to developed countries (11\% USA). ${ }^{2,3}$ It has been found to be $24 \%$ in our study. 
Cochrane review 2004 on preterm labor concludes that tocolysis is definitely indicated before 34 weeks gestational age, this is because of the reduction in number of women delivering within next 7 days and resultant decrease in neonatal morbidity. ${ }^{16}$ In our study, it was found that tocoloysis delayed delivery in $90 \%$ of total cases and maximum in 28-34 gestation age. This delay in delivery allows times for the steroids to accelerate pulmonary maturity and neonatal survival.

Isoxsuprine was the first beta sympathomimetic drug used to inhibit preterm labor in 1961. Many studies have shown it to have limited therapeutic value in light of unpleasant side effects and efficacy. ${ }^{10-13}$ Nifedipine, a calcium channel blocker was first used clinically as a tocolytic by Ulmsten et al in 1980. Since then it has emerged as a safe and effective tocolytic. ${ }^{6,14,15}$ In the present study, nifedipine shows significantly better efficacy $(90 \%)$ in delaying delivery for $24 \mathrm{hrs}$ as compared to isosuprine $(76 \%)$. Kalita et al reported a success rate of $84 \%$ with nifedipine and $64 \%$ with isosuprine. ${ }^{12}$ Read et al reported a success rate of $83 \%$ with nifedipine. ${ }^{15}$ Kupfermine et al reported $83 \%$ success with nifedipine and $77 \%$ with ritodrine.

The mean prolongation of pregnancy in the present study was 22.4 days with nifedipine and 16.5 days with isoxsuprine. Kalita et al reported mean prelongation of pregnancy as 31.16 days with nifedipine and 23.06 days with isoxsuprine. ${ }^{12}$

In our study, no significant difference was noted in maternal and neonatal side effects but lesser side effects was seen with nifedipine. Ferguson, Meyer, Kupfermine and Papatsonis all found nifedipine to be associated with significantly fewer maternal side effects as compared to isoxsuprine. Kalita et al have reported a significantly higher incidence of side effects with isoxsuprine than with nifedipine. ${ }^{1,4,9,12,17}$ Tewari et al have reported a much higher incidence of tachycardia in both groups. ${ }^{11}$ In the present study, transient hypotension, nausea, vomiting, tachycardia, chest pain, headache in $20 \%, 10 \%, 46 \%, 4 \%$, $30 \%$ in nifedipine group. Headache was more in nifedipine group as seen in present study and that of Rayamajhi et al. ${ }^{18}$ In our study, cardiovascular side effects were more seen in isoxsuprine group. This is comparable to the study of Read and Wellby who observed more cardiovascular side effects with isoxsuprine compared to nifedipine. ${ }^{15}$

The RCOG recommends that if a tocolytic drug is to be used, ritodrine is no longer the first choice. ${ }^{19}$ Atosiban and nifedipine appear to be preferable as they have fewer adverse effects and seem to have comparable effectiveness. The reported experience with nifedipine as a tocolytic has been found to be reassuring in view of the increasing evidence of its efficacy and safety combined with its ease of administration; it appears likely that nifedipine will play an expanded role in suppression of preterm labor.
Funding: No funding sources

Conflict of interest: None declared

Ethical approval: The study was approved by the Institutional Ethics Committee

\section{REFERENCES}

1. Kupfermine M, Lessing JB, Yaron Y. Nifedipine versus ritodrine for suppression of preterm labor. $\mathrm{Br}$ J Obstet Gynecol. 1993;100:1090-4.

2. Martin JA, Kochank KD, Strobino DM. Annual summary of vital statistics 2003. Pediatics. 2005;115:619-39.

3. Begum F, Buckshee K, Panda JN. Risk factors associated with preterm labor. Bangladesh Med Ras Coune Bull. 2003;29:59-66.

4. Ferguson JEII, Dyson DC, Schutz T. A comparison of tocolysis with nifedipine or Ritodrine: analysis of efficacy and maternal fetal and neonatal outcome. Am J Obstet Gynecol. 1990;163:105-12.

5. Singh N, Singh U, Seth S. Comparative study of Nifedipine and Isoxsuprine as Tocolytics for Preterm labor. The Journal of Obstetrics and Gynecology of India. 2011;61:512-5.

6. Ulmestein U. Treatment of normotensive and hypertensive patient with preterm labor using oral nifedipine. Arch Gynaecol. 1984;236:69-72.

7. Ferguson JE, Dyson DC, Holbrook HR. Cardiovascular and metabolic effects associated with nifedipine and ritodrine tocolysis. Am J Obstet Gynecol. 1981;161:788-95.

8. Ulmestiene U, Anderson K, Wingercep L. Treatment of premature labor with the calcium antagonist nifedipine. Arch Gynecol. 1980;229:1-5.

9. Meyer WR, Randall HW, Graves WL. Nifedipine versus Ritodrine for suppressing preterm labour. J Reprod Med. 1990;35:649-53.

10. Walkinsaw SA: Preterm labour and delivery of the preterm infant. In: Geoffrey Chamberlain (ed).Turnbull's Obstetics. London: Churchill Livingstone; 1995:609-627.

11. Tewari S, Sachan A, Gulati N. Nifedipine, a safe alternative tocolytic in preterm labour. The Indian Practitioner. 1997;50:307-10.

12. Kalita D, Goswami A, Mazumtar KL. A comparative study of nifedipine and isoxsuprine hydrochloride in the management of preterm labour. J Obstet Gynecol India. 1998;48:47-50.

13. King JF, Grant A, Keirse MJNC, Chalmers I.? mimetics in preterm labour : An overview of the randomized controlled trials. Br J Obstet Gynecol 1998;95:211-22.

14. Ulmsten U, Andersson KE, Wingernp L. Treatment of preterm labour with the calcium antagonist nifedipine. Arch Gynecol. 1980;229:1-5.

15. Read MD, wellby DE. The use of a calcium antagonist (nifedipine) to suppress preterm labour. Br J Obstet Gynecol. 1986;93:933-7.

16. King JF, Flenady VJ, Papatsonis DNM. Calcium channel blockers for inhibiting preterm labor 
(cochrane review). The cochrane library. Chichester: Wiley; 2004.

17. Papatsonis DNM, Blaker OP, Vangeijn HP. Nifedipine and Ritodrine in the management of preterm labour: a randomized multicenter trial. Obstet Gynecol. 1997;90:230-4.

18. Rayamajhi R, Pratap K. A comparative study between nifedipine and isoxsuprine in the management of preterm labour. Kathmandu University Med J. 2003;85-90.
19. RCOG. Tocolytic drugs for women in preterm labor. In. Clinical guideline no. I (B). London: RCOG Press; 2002.

Cite this article as: Jain P, Suman S, Mishra MG. Comparative study of nifepidine and isoxsuprine in suppression of preterm labour. Int J Reprod Contracept Obstet Gynecol 2016;5:3754-7. 